\title{
FORM AND MEANING \\ IN ARCHITECTURAL THEORY
}

\author{
A
}

Often architectural theory has been articulated on prescriptive views about what architecture should be, rather than on views formulated from historical experiences and examples of architecture. In this paper I will try to offer readings of architectural form by looking at a historical example from classical Ottoman architecture and at contemporary examples, to show how different architectures treat form. In examples taken from Sinan's architecture, symbols are investigated in relation to movement, to urban settlement, to religion and power. It is hoped that this analysis will offer an understanding of how the significance of architecture in human experience and in the urban context goes beyond structure and function. 


\section{ABOUT STRUCTURE, FUNCTION AND MEANING}

\section{IN ARCHITECTURE}

Architectural theory has usually tried to give form to meaning and to relate content to form or to interpret form in terms of symbols and social significance. Meaning and form concern all human enterprise, all art and craft; therefor it is important to understand how architectural theory or theory in general approach meaning. Jurgen Habermas, explains how theory has religious roots in ancient Greek culture. Théoros was the person sent by the Greek cities to watch the public games. He would lose himself in the observation of the sacred events. Later, 'theoria' was adopted by philosophy to mean the observation of the cosmos. Theory then becomes the tool of 'Logos' cleaned of all doubt. Theory eventually meant how one traces the changes in nature and becomes educated. "Theory imprints its form on life, it is reflected in the ethos, in other words, in the attitude of the one who submits himself to its discipline." In our day theory is understood as a critical approach to a subject, often prescribing a definition about the role and function of that subject. The function of theory is to define through proposals or to explain through models or examples. However, in architecture, theory nowadays is often seen as the exclusive right of critics, excluding any possibility of deriving interpretations from historical examples about what architecture is. My approach will be contrary to this supposition. As Théoros who observes the sacred events, I will look at examples of architecture and try to lose myself in their meaning and form in formulating a theory.

I have two guides. George Bataille who had written quite extensively on what architecture meant and the Ottoman architect Sinan whose buildings speak for themselves and whose writing reflects how forms can mean.

Sinan wrote about his architecture, but not in the sense that we understand architectural theory today. Besides, till the eighteenth century there was very little literature that could be considered directly as architectural theory. Therefore it is of course not misplaced to treat of Sinan's texts, which were dictated to his friend the Poet Mustafa Sai Çelebi, as expressions of architectural theory. ${ }^{2}$

An important claim that I would like to start with belongs to Dennis Hollier in his important book entitled 'Against Architecture'. ${ }^{3}$ Hollier claims that architecture is what is left of a building after its functionality and its structure are put aside. According to Hollier, buildings, whether they are monuments, temples or houses are only means for something else; buildings always refer to something outside themselves. A building is never built for itself, it is built for a reason outside itself. The interior of a temple or of a house is empty, 


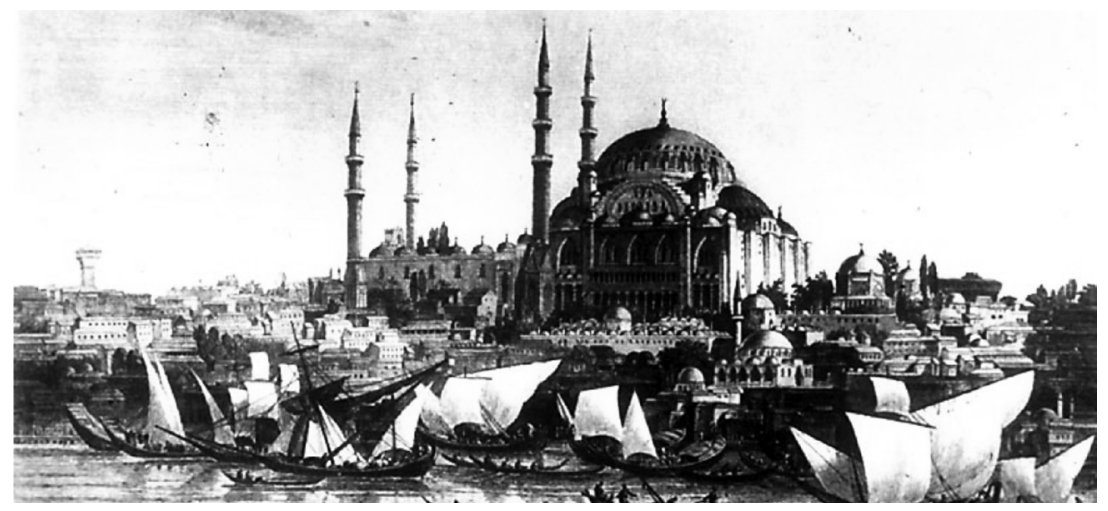

Figure 1. The Süleymaniye Mosque seen from the port inside the Golden Horn, lithograph by a 16th century traveller.

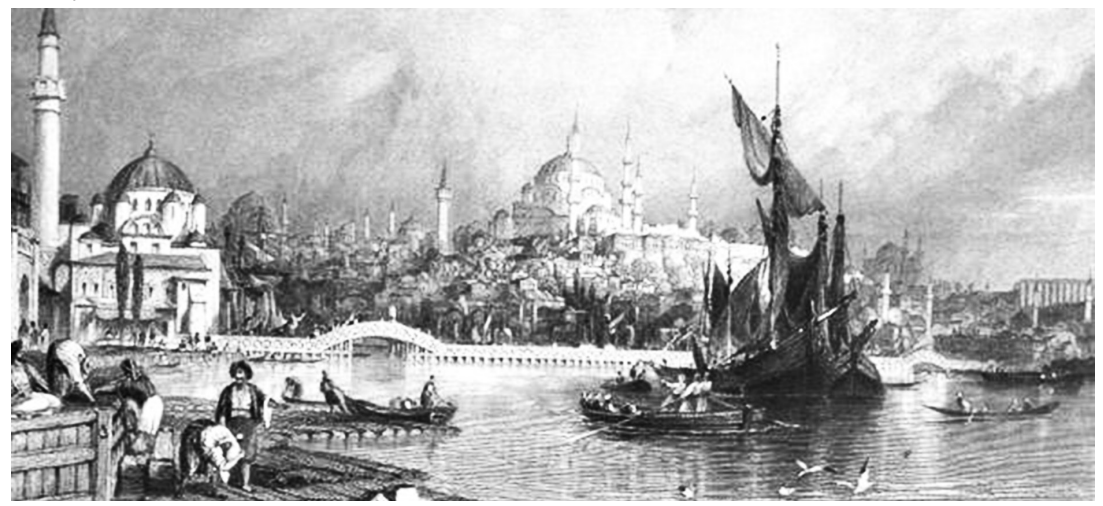

Figure 2. The Sokollu Mosque in the foreground with Suleymaniye Mosque in the distance, lithography by a 17 th century traveller

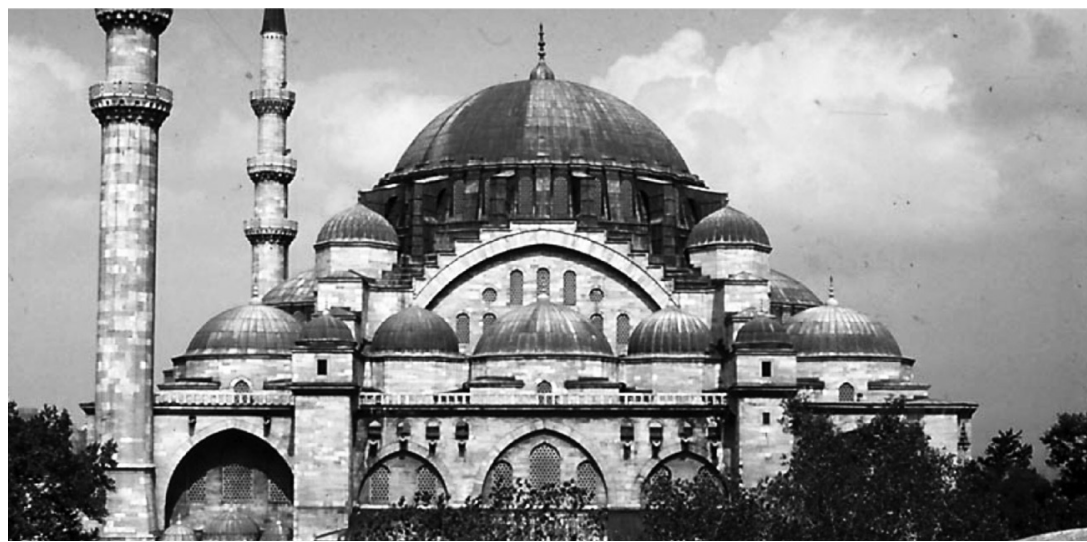

Figure 3. The Pyramidal Form - Suleymaniye Mosque

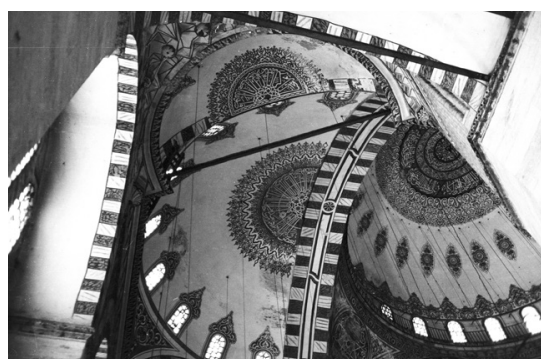

Figure 4. The interior of the Rüstem Paşa Mosque $F$ (c.1566) rich with tile decoration

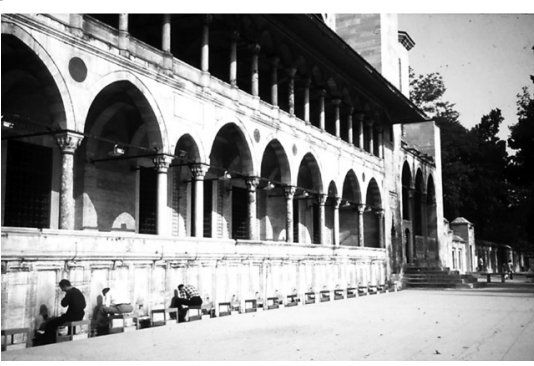

Figure 5. The Ablution fountains on the outer wall of the Suleymaniye Mosque 
it is when humans or gods fill this emptiness that the aim of its existence is fulfilled; this emptiness is filled with something other than architecture. It is only the symbolic status of the building that makes it possible to transcend this exteriority. In reality, architecture is the identity of a building that cannot be reduced to its structure. And this means that architecture is the focus or the frame of representation. Architecture is what is represented beyond structure and beyond function. Architecture beyond structure and beyond function is meaning or representation. In other words architecture is the metaphysical presence of a building.

\section{IDEA AND FORM}

In ancient Greek the word 'idea' was the word 'form' in Latin. Therefore an idea is the origin of form; there is no form without idea. Form is the result of the relation with an idea, with a purpose; idea is the generative force of form. Therefore there cannot be form without idea.

Likewise in art, in science, in technology or craft, form is always the result of an idea. Idea and form are inseparable. It is in the form that we can go back to the idea, to intention and to the original idea that is the source of the process of creation of coming into being. Art and science, technique and craft have always existed within an endless labyrinthian realm. Their limits are unclear, they cannot ever be defined in finite terms. They are like the Minotaur, a mixture of various identities. Architecture, likewise, is difficult to describe and define. It is not the building, it is not the structure, nor is it the function. All throughout history, architectural theory has tried to deal with this problem, often evading a description and formulating prescriptions about what it should be.

Does the key to understand architecture lie in the relation of form to meaning? Before the Enlightenment, generally speaking architecture was only those buildings that already had a symbolic function, which could be religious or commemorating an event or a person. The meaning came ready with whatever form that building had to have according to the exigencies of structure. There were some architectural elements evolved through cultural processes that had to be included in architectural types, such as the minaret and dome for a mosque, towers for cathedrals, etc. Apart from these, often meaning was directly represented through images, such as the narrative designs on glass or the sculptural reliefs on cathedral doors. It is only after the Enlightenment, when new types of buildings began to come into existence because of the new social need created by industrialization that form began to be investigated as a source of meaning. Rather than typical symbolic elements that previously had to be used to create meaning, form in its abstract geometry began to be interpreted and used to refer to ideas and ideals. 


\section{HOW FORMS MEAN - SINAN'S ARCHITECTURE}

In reference to the above explanations, I will treat of examples from fifteenth century architecture, and from a few contemporary buildings, trying to understand what is left as the metaphysical presence of architecture when function and structure are left aside. How forms mean, beyond the building. I will start with the meanings that are conveyed in Sinan's buildings, both as we observe them in the context of the city and when we observe them as we use or as we inhabit them.

I propose four ways of reading Sinan's work. First as urban sculptures that help us to orient ourselves in the city. Süleymaniye was the entrance to the city in the Ottoman times when the port was inside the Golden Horn. Süleymaniye, seen from the Golden Horn was like a sentinel guarding the city; it was the face, the façade of the city.

Secondly all of Sinan's mosques in Istanbul were related to each other visually. From any of Sinan's İstanbul mosques you can see the Süleymaniye Mosque, which represented Sultan Suleiman and his power, as well as being the intellectual center of Istanbul with its four educational institutions (madrasas). This creates a certain mapping, a certain network to read the urban structure.

Especially the mosques built for Sultans or for the princes are of pyramidal form that symbolizes the primal mountain, the first earthly structure, which is a natural temple. The form of Sinan's mosques is constituted by the connection of two symbolic and pure forms: the square and the circle; in three dimensions, the cube and the sphere. The sphere represents the heavens, what is infinite

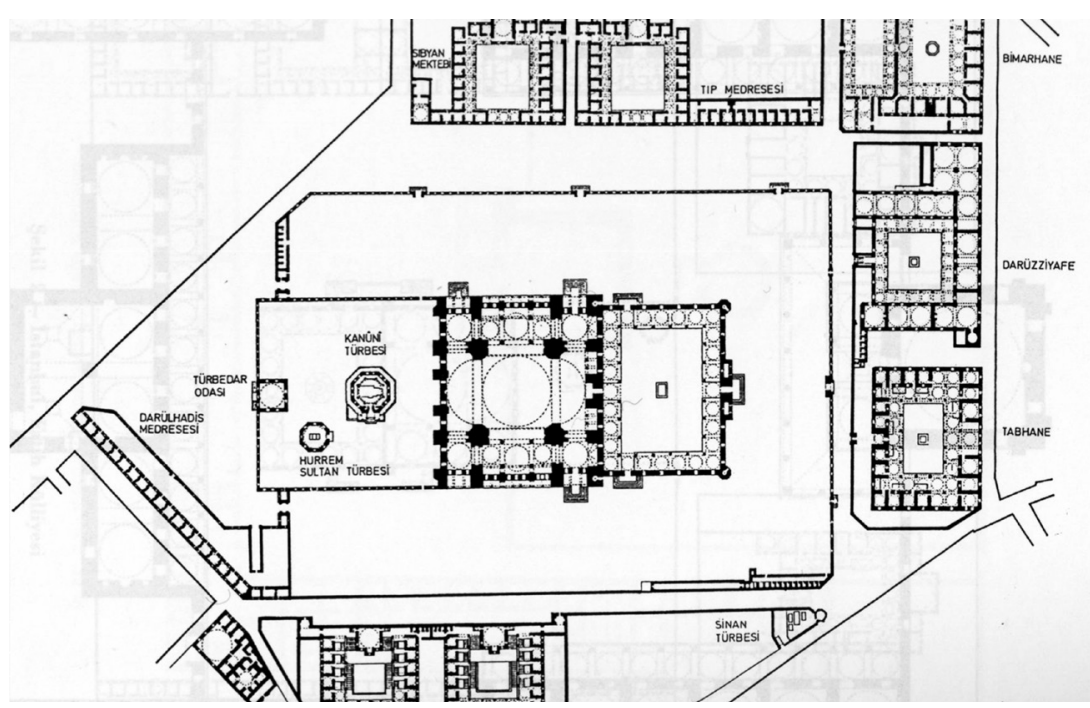

Figure 6 . The settlement plan of Suleymaniye Mosque with its dependencies, such as madrasas, soup house, hospital, around its central core 
and sacred, the square represents the world of mankind with the four cardinal points, North, South, East and West. The world of man rotates within the infinite realm of the sacred, of God and of heavens. The sphere covers the rectangular space of Sinan's mosque. But this symbolism is all inclusive: you find it in the decorative patterns on wood, on marble and on some carvings. The building is an exclusive symbol of man's relation to God. The whole complex stands in the middle of the city, at one of its highest points and symbolizes the intellectual and spiritual center with its many madrasas, centers of learning. It also points to the fact that the center of the Empire with its ruler, the Sultan, represents the highest attainment of learning.

Another important symbolism and meaning is apparent in the site planning of mosques or rather of külliye's, which contain different buildings of social function, such as schools, soup houses, hospitals, etc. arranged around the focal center of the mosque. The arrangement is like water rings around a stone falling in water: first the space right under the central dome, then the extended spaces under the secondary domes, or the half domes, as we can see both in the Süleymaniye and in Şehzade mosque. Then we have the semi open spaces around the mosque, which are the portico, the galleries on the sides and as in the Selimiye the gallery at the back. Then we have the open space surrounding the building; we have then the other building encircling the main building, then we have a circulatory space, a path, etc. All this revolving arrangement in the spiral represents a conception of space and time that is also found in Ottoman music. The spiral is one of the most common forms of dynamism and growth in biology and astronomy, and has its equivalent in geometrical shapes and mathematical systems. Many great artists have used it in their buildings or musical compositions either consciously or unconsciously. Not only does it create a harmonious and naturally pleasant relationship, but can also be seen as a symbol of life and of infinity. In many of Sinan's mosques the spiral is used in the system of circulation, creating a kinetic experience that is akin to the Dervishes dance.

In Sinan's work the exact equivalence of the interior and the exterior form, the way the convex and the concave are folded upon each other results with a form where structure and function are no longer external to architecture, they are both dissolved in the meaning of what Sinan's architecture stands for.

How was this symbolism in which both structure and function are dissolved, seen by Sinan? In his treatise, the Risale_i Ebniye which Sinan dictated to his poet friend Mustafa Sai, he narrates that on a certain day he was going 
all around Istanbul to look for a pleasant spot, a sort of picnic or promenade place. In the end after going around the city, he narrates that they entered the Şehzade mosque and that with all that it offered to the senses it was the place they had been looking for. Obviously the interior of Sinan's mosques are meant to represent the paradise Garden. Every aspect of the interior symbolizes very closely the descriptions of paradise in the Koran. The sound of water in the Selimiye, the floral designs on tiles, the reflections of light. In the Rüstem paşa Mosque in Eminönü this symbolism is carried to the extreme.

The central door has two panels on either side representing trees and flowers and Heaven's door. Sinan is also very attentive to the quality of sound in his buildings. In this tiny mosque placed in the middle of a very busy commercial environment, the double portico, its being elevated over the street guarantees absolute quiet and peace within the interior space.

All that we have talked about up till now concerns Sinan's buildings' relation to the user, to the human; the human contact. The physical relationship to the mosque, the bodily experience of the huge building, this intimate contact is of course common for many Islamic mosques because of the physically active form of prayer. However, Sinan goes further in this and makes sure that the relationship between the huge monument and the pious is something that will not be missed and will be a deep experience: it is the building, in the Süleymaniye which offers the pious the water for ablution. Water, being the main symbol and source of life is put to many symbolic uses in the mosques of Sinan. We see it also in the Selimiye right under the elevated platform.

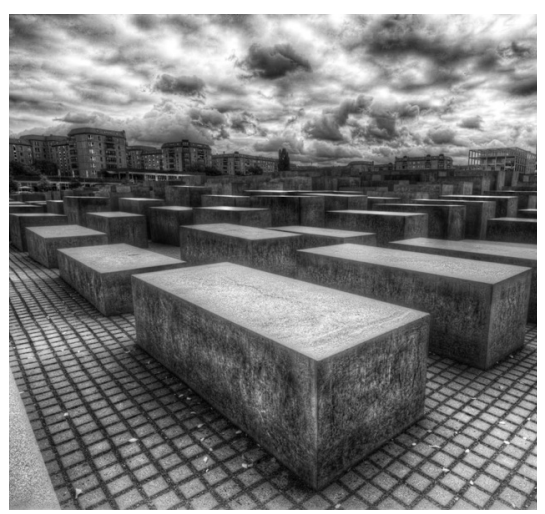

Figure 7 . Peter Eisenman, Berlin Memorial https://www.google.com.tr/search?q=peter+eisenma $\mathrm{n}+$ memorial

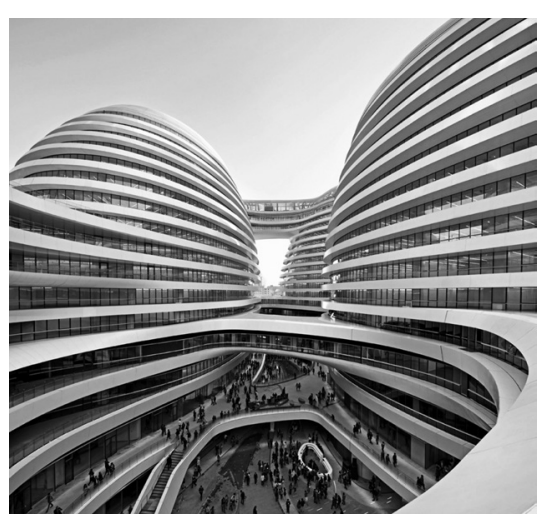

Figure 8. Zaha Hadid, Beko Building https://www.google.com.tr/ search?q=zaha+hadid+architectureGalaxy Soho photo, archdaily.com 
Sinan is conscious that good architecture will be an educative example, and that art and architecture are cultural meanings and knowledge passed on to young generations. In one of his treatises he says 'I have put special doors on the domes, so that the experts will study my domes and enjoy their beauty'. The mosque, which is an object of adoration to God, is as beautiful as Nature. The domes are described by Sinan as the waves of the sea which change color with the lights of the Sun. But light is the supreme symbol. Its source should be the spirit or God, hence, as Burelli writes, the windows are often covered with colored glass or opaque material so that the sun's position cannot be understood, creating an effect as though the light is coming from every direction, from all the heaven.

\section{FORM AND MEANING IN CONTEMPORARY ARCHITECTURE}

From contemporary architects Peter Eisenman can be chosen as the representative of deconstruction and Zaha Hadid for her winding and fluid forms. In both of these architects' works, as well as many others the meaning that is associated with function is eliminated. When we look at these buildings we do not have any idea of what it is used for. Thus, in one way, function is eliminated, leaving place to understanding form in its symbolism. Yet, often form is created just for itself without any external reference. After a while this becomes overbearing and repetitious, since it does not relate to human understanding or apperception. On the other hand, many of these forms lead one to ask questions about structure and gravity. Therefore, we are not yet totally in the realm of architecture in its metaphysical implications, although for many architects who wanted to avoid direct meaning of form and who chose a conceptual, philosophical idea of architecture, this has not been possible because there is no empirical guide to lead us beyond the materiality of the building.

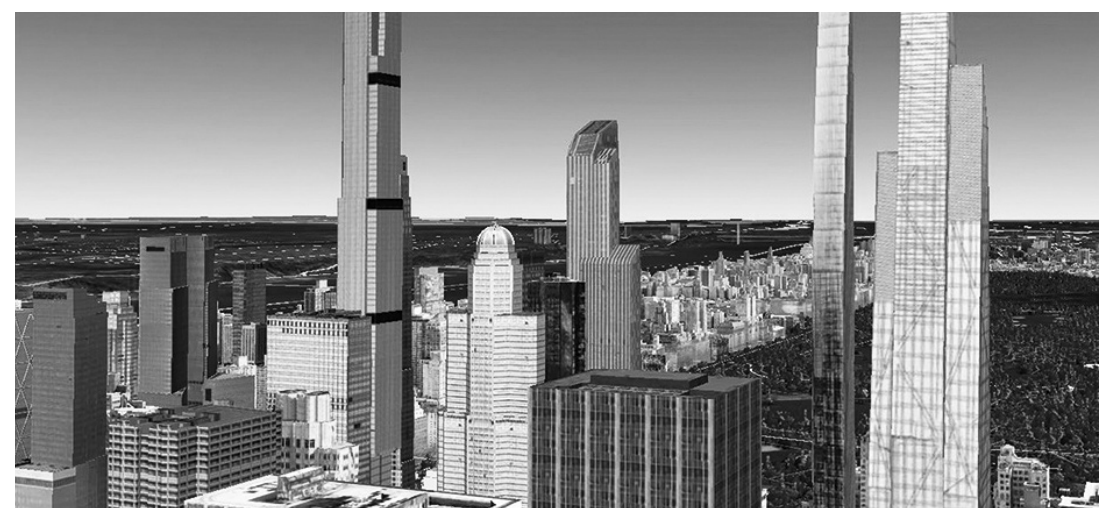

Figure 9. Armand Boudreaux / YIMBY / Google Earth - A rendering of the condominium towers planned or under construction at 225 West 57th Street. From the article of Martin Filler, 'New York, Conspicuous Construction' - New-York Review of Books, April 2, 2015, Vol. 62, No 6 
Often, straight lines or curves, geometric shapes are not appreciated only for their own worth, but become related to questions or affects of our perception related to gravity, to stability, to understanding order, orientation and sequence. What is claimed in De-constructivism as related to the philosophical treatises of Derrida have been tried to be translated into physical form where gravity and laws of physics play primary roles. With the buildings of Zaha Hadid where a cantilever form reaches towards us, there are two ways we can respond. If we are too close, maybe such a form is felt as something sublime and one does not ask to understand it. Or, it can create fear and anxiety. As Nikos Salingaros has mentioned about many Modernist architectural forms, where horizontal lines are repeated, a certain anxiety is created because horizontality means passivity, it may mean death and inability to move. ${ }^{5}$ The horizontal bears heavily on our body. Buildings, structures and forms' meanings are first sensed through the body and through our body's relationship to those forms. Peter Eisenman or Liebeskind have used these anxiety causing forms in specific cases related to the Holocaust, where they are put to legible use.

\section{CONCLUSION}

As I tried to demonstrate form and meaning are certainly related, but not outside human experience. Sinan's buildings, and certainly some other fifteenth and sixteenth century buildings such as those of Borromini or Michelangelo were concerned to create an architecture to remain intelligible after all concerns of structure and function. In this quest the relation to human sensibility was the key determinant. In many new buildings where the incentive is to create original form the human content has been lost. With old religious buildings, even if God was the focus, man related to it through his/her bodily senses; through music, through color, through forms that were almost universal such as the circle or the square and triangle. Today when individual subjectivity seems to be so important, what buildings mean is usually beyond and beside human sensibility. Often they are related to power and money as evident in Fig. 8 of the new New York Condominiums which the author Martin Filler likens to cash registers. 
Jurgen Habermas, La Technique et la Science comme “idéologie”, tr. and with a preface by Jean- René Ladmiral, (Paris, Gallimard, 1973), 134.

Denis Hollier, Against Architecture - The Writings of Georges Bataille, trans., Betsy Wing, (Cambridge, Massachusetts: MIT Press, 1992).

Nikos A. Salingaros, Twelve Lectures on Architecture, Algorithmic Sustainable Design, (Nikos A Salingaros \& Umbau-Verlag, 2010), 49. Rifat, edited by Samih Rifat, Arzu Karamani Pekin. İstanbul: Koçbank, 2002.

Habermas, Jurgen. La Technique et la Science comme "idéologie”. Trans. and with a preface by Jean- René Ladmiral. Paris, Gallimard, 1973.

Hollier, Denis. Against Architecture - The Writings of Georges Bataille. Trans., Betsy Wing. Cambridge, Massachusetts: MIT Press, 1992.

Salingaros, Nikos A.Twelve Lectures on Architecture, Algorithmic Sustainable Design. Nikos A Salingaros \& Umbau-Verl ag, 2010. 
Kompletno istraživanja objavljeno je u knjizi The indispensable excess of the aesthetics: evolution of sensibility in nature (Neizostavni višak estetike: Evolucija senzibiliteta u prirodi, Lexington 2015).

KLJUČNE REČI: EVOLUTIVNA ESTETIKA, DARVIN, BIOSEMIOTIKA, ZOO-POETIKA, AESTHESIS, ZOO-ESTETIKA, EVOLUCIJA

\section{OBECANJE MEDIJSKE ARHEOLOGIJE Nadežda Čačinovič}

Medijska arheologija nudi novi i neophodan alat za suočavanje sa mnoštvom fenomena koje tako neselektivno - anahrono ili na druge načine - prepoznajemo kao umetnost i klasifikujemo kao umetnička dela. Rad pokušava da naglasi razliku u poređenju sa srodnim gledištim: teorije kulturne transmisije, materijalnosti kulture, logike estetskih režima itd. Moglo bi se nazvati "mediji pre medija" (i prati Kitlera (Kittler)) ili kopati sa Zilinskim u "Duboko vreme medija" (Deep Time of the Media) sa dobrom vezom prema "istoriji pristupa čula" ili ići pravo sa Jusi Parikom i Erki Huhtamom (Jussi Parikka, Erkki Huhtamo) i koristiti "medijsku arheologiju”: ali je uvek priznanje protejske prirode umetnosti i arhitekture.

KLJUČNE REČI: MATERIJALNOST KULTURE, ISTORIJA ČULA, MEDIJI, KULTURNA TRANSMISIJA

\section{FORMA I ZNAČENJE U ARHITEKTONSKOJ TEORIJI Jale Nejdet Erzen}

Često je arhitektonska teorija bilo jasno izražena propisanim stavovima o tome šta bi arhitektura trebalo da bude, pre nego stavovima formulisanim od istorijskih iskustava i primera arhitekture. U ovom radu ću pokušati da ponudim čitanje arhitektonske forme gledajući istorijski primer iz klasične otomanske arhitekture i savremene primere, pokazujući kako različite arhitekture tretiraju formu. U primerima Sinanove arhitekture, simboli su istraživani u odnosu na kretanje, urbani sklop, religiju i moć. Ideja je da će ova analiza ponuditi razumevanje značaja arhitekture u okvirima ljudskog iskustva i urbanog konteksta kojii dopire izvan strukture i funkcije.

KLJUČNE REČI: ARHITEKTURA, SINAN, FORMA, ZNAČENJE, STRUKTURA, TELESNI ODNOSI

\section{POL ŠIRBART I UTOPIJA OD STAKLA}

\section{Tyrus Miller}

Ovaj rad će razmotriti arhitektonske spise nemačkog ekspresionističkog pisca Pola Širbarta (Paul Scheerbart), sa fokusom na njegovoj fascinaciji staklom kao arhitektonskim i metaforičkim materijalom. Diskusija je o Širbartovom arhitektonskom traktatu Arhitektura stakla (Glass Architecture), njegovom romanu Siva tkanina (The Grey Cloth) i srodnim tekstovima o arhitekturi stakla. Širbart predstavlja alternativnu tradiciju unutar arhitektonskog modernizma, koja gleda na staklo kao na konstruktivan materijal koji predstavlja modernost kroz izlaganje strukturalnih elemenata, takođe u službi komfor forme prema funkciji. Širbart, nasuprot tome, smatra staklo nosiocem boje i multiplikatora svetlosti, koje je video kao sposobnog da transformiše čovekovu okolinu i ostvari pozitivne efekte na pojedince i kolektive. On je video svetlost kao kulturnoformativnu, a arhitekturu stakla kao sredstvo kojim izgrađeno okruženje može da poveća moderni kulturalni utopijski potencijal. Takođe, ukratko ću razmotriti i uticaj Širbarta na anarhističkog arhitektu Bruna Tauta (Bruno Taut) i na razmišljanja Valtera Benjamina (Walter Benjamin). 